\title{
Evaluation of insulation systems by in situ testing
}

\author{
I. Enache ${ }^{1}$, D. Braga ${ }^{1}$, C. Portet ${ }^{1} \&$ M. Duran ${ }^{2}$ \\ ${ }^{1}$ Research and Development Department, Actis Limoux, France \\ ${ }^{2} E M M$, Bruxelles, Belgium
}

\begin{abstract}
Due to the global warming of the earth, the energy performance of buildings is now a crucial subject. In order to have an accurate comprehension of the energy loss of a building, we have developed real time in-situ tests for the thermal performance of building insulation systems. The test cells are pitched roofed with two gable walls, have the same interior and exterior dimensions, are placed in outside weather conditions and are constructed with the same materials (apart from the roof and gables insulation). All cells are heated in the same way. The temperature inside the test cell is maintained at the same specified level in winter by fan heaters. By comparing the air temperature within the test cell to the outside weather conditions and monitoring the energy required to maintain the internal temperatures, the real life thermal efficiency of each insulation system can be estimated. This paper deals with the results obtained over several test centres around Europe using a thin multi-layer reflective insulation product for the insulation of the first test cell, mineral wool for the insulation of the second one, and without insulation for the third one.
\end{abstract}

Keywords: in situ testing, real life thermal efficiency, thin multifoil insulation.

\section{Introduction}

Reducing $\mathrm{CO}_{2}$ emissions has become one of the most important challenges for all industrial sectors. Concerning the building industry, there has to be a significant improvement in thermal performance. New regulations continuously reinforce the requirements on the contribution of building products to energy saving. 
Nowadays, the estimate of energy demand for a building is made with dedicated software that allows a study of the impact of different solutions contributing to the building energy requirement. Insulation products are a key parameter. Their thermal properties are estimated by standardized guarded hot plate or hot box measurement. However, important differences between the standard calculation [1,2] and in situ measurements can be observed. A detailed report from the Building Research Establishment Ltd [3] has concluded that there are important differences, in certain cases equivalent to almost $30 \%$, between the calculation of the coefficient of thermal transmission $U$ under the norm ISO 6946 [4] and the measurements in situ made by the Alba Building Science company on the walls of buildings built between 1995 and 1999.

In this context, the European Multifoil Manufacturers association (EMM) has chosen to categories different insulation systems using in situ tests. This method has the advantage of taking into account the influence of real conditions on the thermal performance of different insulation solutions. In this way this technique gives much more realistic information about the thermal behaviour of the tested insulation product once installed.

In situ tests developed by EMM and presented here concern three identical buildings insulated with different insulation systems: one insulated with a thin multi reflective product (MF), one insulated with $200 \mathrm{~mm}$ of mineral wool (MW) and the last one is not insulated. The in situ measurements are also compared with simulation results obtained with TRNSYS ${ }^{\circledR}$ software.

\section{Experimental part}

\subsection{Structural description of the test cells}

Three test cells in timber frame representative of an attic that can be converted, with a roof surface about $35 \mathrm{~m}^{2}$, outside dimensions of $4 \times 7 \mathrm{~m}^{2}$ on floor area and a height of $3 \mathrm{~m}$ were used for the described tests (figure 1). The access to each test cell is gained through an insulated airlock situated on the gable wall. The gable walls and the attached airlock are made of $23 \mathrm{~mm}$ thick plywood. The roof $\left(36^{\circ}\right.$ pitch), is traditional, made up of rafter of $8 \times 11 \mathrm{~cm}$ with a roof void of $48 \mathrm{~cm}$ whilst the roofing is made of clay tiles. The floor is timber with an under floor void and over-insulated with $20 \mathrm{~cm}$ of polystyrene and $10 \mathrm{~cm}$ of mineral wool.

In order to obtain a reasonable accuracy of the thermal performance of the insulation system, the cells have no windows and no controlled ventilation system. Also, the temperatures of the airlock entries and under floor spaces are maintained at the same level as inside; therefore the thermal exchanges take place only through walls insulated with the tested material.

\subsection{Insulation set-up}

Insulation products tested are (figure 2):

- Non-commercial thin $(45 \mathrm{~mm})$ multi reflective insulation product (MF) with a core thermal resistance of $1.25 \mathrm{~m}^{2} \mathrm{~K} / \mathrm{W}$ measured with standards methods [1,2]. 
- Mineral wool of $200 \mathrm{~mm}$ (MW) with a declared thermal conductivity of 0,040 $\mathrm{W} / \mathrm{m} . \mathrm{K}\left(\mathrm{R}_{\mathrm{D}}=5 \mathrm{~m}^{2} \mathrm{~K} / \mathrm{W}\right)$. An additional and continuous vapour control layer made of polyethylene foil $(0.2 \mathrm{~mm})$ was placed between mineral wool and plasterboard.

- The last cell had no insulation above the plasterboard.

The layout has been contrived under the manufacturers' instructions [5,6]. A HPV under tile liner was placed under the tiles in each cell.

\subsection{Test method}

In order to analyse the thermal behaviour of the insulation systems in different conditions, the three cells have been placed on exposed sites in three different

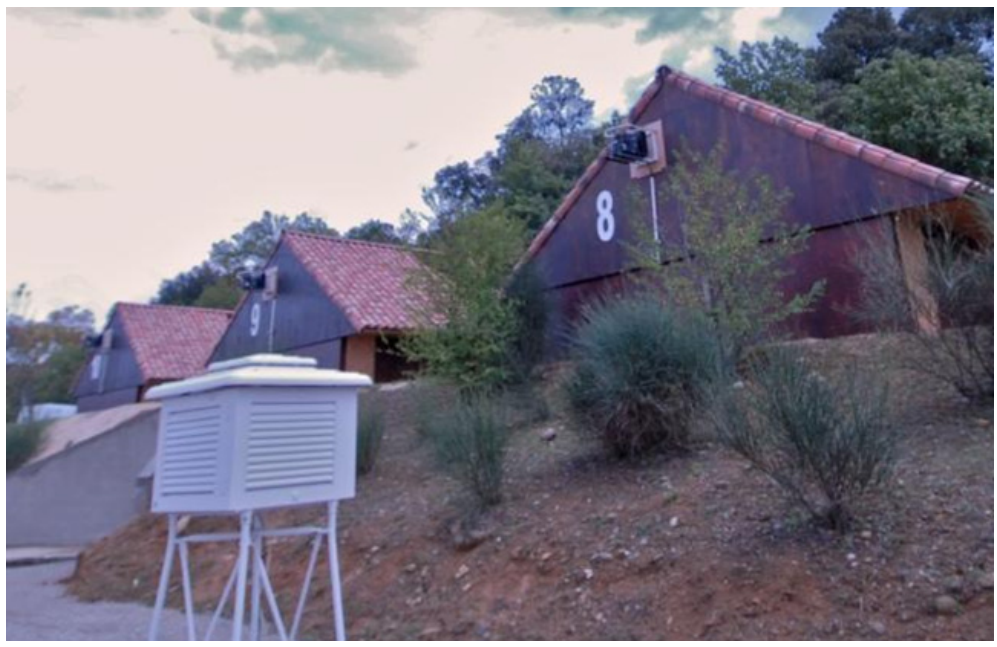

Figure 1: $\quad$ Photography of the test cells.

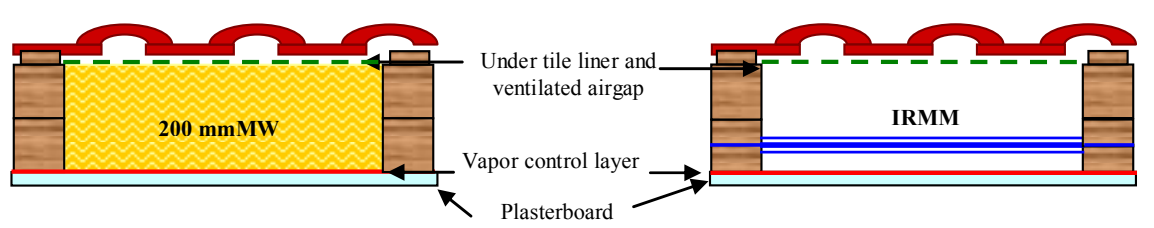

Figure 2: $\quad$ Scheme of roof constructions (for the non-insulated cell, the same configuration was contrived without any insulation)

Table 1: $\quad$ Characteristics of the test sites.

\begin{tabular}{|l|c|c|c|c|}
\hline Site & $\begin{array}{c}\text { Average } \\
\text { temperature }\end{array}$ & $\begin{array}{c}\text { Temperature } \\
\text { variation }\end{array}$ & $\begin{array}{c}\text { Wind } \\
\text { speed }\end{array}$ & $\begin{array}{c}\text { Solar } \\
\text { radiation }\end{array}$ \\
\hline North of Europe (lat $\left.54^{\circ} \mathrm{N}\right)$ & Low & Very low & High & Low \\
\hline Center of Europe $\left(43^{\circ} \mathrm{N}\right)$ & High & High & High & High \\
\hline South of Europe $\left(40^{\circ} \mathrm{N}\right)$ & High & Very high & Low & Very high \\
\hline
\end{tabular}


regions of Europe with very different weather conditions. The typical weather characteristics of the three sites are shown in table 1.

\subsubsection{Instruments inside the testing cells}

Each cell has been equipped with two temperature sensors located at $1.50 \mathrm{~m}$ above the floor. The sensors are placed in an open grey PVC tube in order to protect them from air movements which might affect the measurements. Seven other temperature sensors are installed in the cell in order to control the temperature distribution in the cell volume. During test in winter conditions, the temperature in the cells is maintained at a constant level with two fan heaters of $1 \mathrm{~kW}$. Current and voltage measurements using calibrated transducers allow, in each cell, the determination of the exact energy consumption. A meteorological station, located nearby the cells is equipped to permanently record the following weather parameters: temperature, relative humidity, pressure, global solar radiation and wind speed. All measurements are registered on a constant rate (one per minute)

\subsubsection{Cells calibration}

Before the test starts, a calibration phase takes place in order to ensure that the 3 test cells are similar in terms of internal dimensions and thermal performance when insulated with the same product. During this phase, the three cells are insulated with $200 \mathrm{~mm}$ mineral wool and the temperature inside is maintained at the same level for five days. The actual recorded energy consumptions were similar (difference less than 5\%) and therefore the cells are considered to be identical.

\subsubsection{Test of different insulation systems}

After the calibration phase, the cell which consumed the lower amount of energy retained MW as insulation product. The cell which consumed the higher amount of energy is not insulated during the test. Finally, the last test cell is insulated with MF.

Before the test started, new measurements of the cell interior dimensions and air tightness were performed. As we can see in table 2, the three cells are very similar.

Table 2: $\quad$ Interior dimensions and air tightness of the test cells.

\begin{tabular}{|c|c|c|c|c|}
\hline & & Surface $\left(\mathrm{m}^{2}\right)$ & Volume (m3) & $n_{50}\left(h^{-1}\right)$ \\
\hline \multirow{3}{*}{$\begin{array}{c}\text { North of } \\
\text { Europe }\end{array}$} & MF & 43.62 & 27.78 & 4.60 \\
\hline & MW & 44.18 & 28.37 & 5.00 \\
\hline & Not insulated & 44.41 & 28.45 & 4.85 \\
\hline \multirow{3}{*}{$\begin{array}{c}\text { Centre of } \\
\text { Europe }\end{array}$} & MF & 44.19 & 28.93 & 4.50 \\
\hline & MW & 45.31 & 30.32 & 4.35 \\
\hline & Not insulated & 44.71 & 30.18 & 4.40 \\
\hline \multirow{3}{*}{$\begin{array}{l}\text { South of } \\
\text { Europe }\end{array}$} & MF & 43.93 & 28.15 & 5.29 \\
\hline & MW & 44.51 & 28.72 & 5.57 \\
\hline & Not insulated & 44.59 & 28.79 & 5.72 \\
\hline
\end{tabular}


Table 3: Daily weather conditions and energy consumptions on the south of Europe site.

\begin{tabular}{|c|c|c|c|c|c|c|}
\hline \multicolumn{7}{|c|}{ South of Europe } \\
\hline Date & Temp $\left({ }^{\circ} \mathrm{C}\right)$ & $\begin{array}{c}\text { Wind speed } \\
(\mathrm{m} / \mathrm{s})\end{array}$ & $\begin{array}{c}\text { Solar } \\
\text { radiation } \\
\left(\mathrm{W} / \mathrm{m}^{2}\right)\end{array}$ & $\begin{array}{c}\text { kWh } \\
\text { MF }\end{array}$ & $\begin{array}{l}\text { kWh } \\
\text { MW }\end{array}$ & $\begin{array}{c}\text { kWh } \\
\text { Not insulated }\end{array}$ \\
\hline 29/01/2008 09:00 & 1.51 & 0.24 & 152.82 & 8.88 & 9.06 & 30.81 \\
\hline $30 / 01 / 2008$ 09:00 & 1.44 & 0.38 & 97.79 & 9.08 & 9.21 & 31.29 \\
\hline $31 / 01 / 200809: 00$ & 2.52 & 0.30 & 157.27 & 9.05 & 8.87 & 29.93 \\
\hline 01/02/2008 09:00 & 6.03 & 1.46 & 57.26 & 7.68 & 7.35 & 26.08 \\
\hline 02/02/2008 09:00 & 4.38 & 1.17 & 144.94 & 8.21 & 7.42 & 28.56 \\
\hline $03 / 02 / 200809: 00$ & 6.99 & 3.00 & 49.90 & 7.48 & 6.83 & 27.22 \\
\hline 04/02/2008 09:00 & 6.16 & 1.29 & 130.35 & 7.44 & 6.76 & 25.81 \\
\hline 05/02/2008 09:00 & 7.46 & 1.14 & 74.17 & 6.57 & 5.89 & 22.62 \\
\hline 06/02/2008 09:00 & 5.74 & 0.43 & 165.90 & 7.01 & 6.13 & 23.38 \\
\hline 07/02/2008 09:00 & 5.09 & 0.21 & 166.90 & 7.44 & 6.67 & 24.21 \\
\hline 08/02/2008 09:00 & 4.59 & 0.17 & 164.42 & 7.10 & 6.31 & 24.64 \\
\hline 09/02/2008 09:00 & 4.32 & 0.24 & 172.50 & 7.27 & 7.00 & 24.97 \\
\hline 10/02/2008 09:00 & 3.45 & 0.22 & 170.31 & 7.45 & 7.26 & 26.04 \\
\hline 11/02/2008 09:00 & 3.75 & 0.23 & 174.30 & 7.59 & 7.39 & 27.10 \\
\hline $12 / 02 / 200809: 00$ & 3.38 & 0.47 & 170.93 & 7.67 & 7.38 & 27.33 \\
\hline $13 / 02 / 200809: 00$ & 2.80 & 0.40 & 173.84 & 7.96 & 7.76 & 28.59 \\
\hline $14 / 02 / 200809: 00$ & 7.29 & 0.49 & 113.83 & 6.76 & 6.57 & 22.98 \\
\hline $15 / 02 / 200809: 00$ & 5.31 & 0.27 & 125.39 & 6.25 & 5.99 & 23.32 \\
\hline 16/02/2008 09:00 & 5.96 & 0.24 & 166.95 & 6.68 & 6.54 & 23.57 \\
\hline 17/02/2008 09:00 & 6.87 & 0.65 & 140.67 & 6.58 & 6.38 & 23.03 \\
\hline 18/02/2008 09:00 & 7.60 & 0.65 & 83.84 & 6.07 & 5.75 & 21.86 \\
\hline 19/02/2008 09:00 & 8.38 & 0.13 & 55.08 & 5.60 & 5.29 & 20.24 \\
\hline $20 / 02 / 200809: 00$ & 7.83 & 0.35 & 111.04 & 5.48 & 5.13 & 20.62 \\
\hline $21 / 02 / 200809: 00$ & 7.06 & 0.52 & 195.91 & 5.87 & 5.56 & 21.70 \\
\hline $22 / 02 / 200809: 00$ & 7.41 & 0.35 & 199.26 & 5.90 & 5.74 & 21.40 \\
\hline $23 / 02 / 200809: 00$ & 10.24 & 0.42 & 141.79 & 5.33 & 5.18 & 18.00 \\
\hline $24 / 02 / 200809: 00$ & 9.63 & 0.30 & 85.40 & 4.98 & 4.73 & 17.90 \\
\hline $25 / 02 / 200809: 00$ & 7.95 & 0.49 & 189.18 & 5.15 & 4.77 & 19.00 \\
\hline $26 / 02 / 200809: 00$ & 8.22 & 0.49 & 124.73 & 5.61 & 5.44 & 19.84 \\
\hline 27/02/2008 09:00 & 10.36 & 0.62 & 116.47 & 4.89 & 4.66 & 17.38 \\
\hline $28 / 02 / 200809: 00$ & \multirow{9}{*}{\multicolumn{6}{|c|}{ Invalid data }} \\
\hline 29/02/2008 09:00 & & & & & & \\
\hline 01/03/2008 09:00 & & & & & & \\
\hline 02/03/2008 09:00 & & & & & & \\
\hline $03 / 03 / 2008$ 09:00 & & & & & & \\
\hline $\begin{array}{l}04 / 03 / 200809: 00 \\
\end{array}$ & & & & & & \\
\hline 05/03/2008 09:00 & & & & & & \\
\hline 06/03/2008 09:00 & & & & & & \\
\hline 07/03/2008 09:00 & & & & & & \\
\hline 08/03/2008 09:00 & 7.20 & 0.85 & 222.45 & 6.67 & 6.51 & 23.31 \\
\hline 09/03/2008 09:00 & 7.04 & 2.01 & 170.01 & 6.78 & 6.63 & 25.03 \\
\hline 10/03/2008 09:00 & 8.39 & 3.46 & 42.27 & 6.73 & 6.60 & 26.54 \\
\hline 11/03/2008 09:00 & 12.79 & 2.44 & 210.80 & 4.36 & 4.21 & 15.97 \\
\hline
\end{tabular}

\section{Experimental and simulation results}

\subsection{Experimental measurements}

In situ testing was performed during the 2007-2008 winter. The weather conditions encountered during this period and the energy needed to maintain the 
temperature set point into the cells $\left(21^{\circ} \mathrm{C}\right.$ for North of Europe, $23^{\circ} \mathrm{C}$ for the two other sites) are presented in tables 3 to 5 .

The energy consumption of the three test cell for the entire test period on each site is given in the table 6 .

Obviously, the energy consumption depends on the number of days of test but also on the weather conditions and the temperature inside the cells. Table 7 gives the values of the thermal transmittance for the each cell on the three test sites.

Table 4: Daily weather conditions and energy consumptions on the centre of Europe site.

\begin{tabular}{|c|c|c|c|c|c|c|}
\hline \multicolumn{7}{|c|}{ Centre of Europe } \\
\hline Date & Temp $\left({ }^{\circ} \mathrm{C}\right)$ & $\begin{array}{c}\text { Wind speed } \\
(\mathrm{m} / \mathrm{s})\end{array}$ & $\begin{array}{c}\text { Solar } \\
\text { radiation } \\
\left(\mathrm{W} / \mathrm{m}^{2}\right)\end{array}$ & $\begin{array}{c}\text { kWh } \\
\text { MF }\end{array}$ & $\begin{array}{l}\text { kWh } \\
\text { MW }\end{array}$ & $\begin{array}{c}\text { kWh } \\
\text { Not insulated }\end{array}$ \\
\hline 14/01/2008 09:00 & 6.91 & 0.71 & 47.50 & 6.45 & 5.45 & 23.54 \\
\hline 15/01/2008 09:00 & 7.20 & 1.64 & 62.66 & 6.43 & 5.55 & 23.49 \\
\hline \begin{tabular}{|l|}
$16 / 01 / 200809: 00$ \\
\end{tabular} & 7.69 & 4.68 & 49.76 & 6.70 & 5.91 & 26.33 \\
\hline 17/01/2008 09:00 & 11.95 & 3.96 & 67.97 & 5.05 & 4.29 & 18.60 \\
\hline 18/01/2008 09:00 & 13.12 & 4.21 & 46.29 & 3.94 & 3.30 & 15.84 \\
\hline 19/01/2008 09:00 & 9.80 & 1.00 & 42.33 & 4.99 & 4.15 & 19.24 \\
\hline 20/01/2008 09:00 & 5.86 & 0.09 & 94.88 & 6.63 & 5.73 & 25.19 \\
\hline 21/01/2008 09:00 & \multicolumn{6}{|c|}{ Invalid data } \\
\hline 22/01/2008 09:00 & 10.78 & 5.71 & 26.20 & 5.15 & 4.85 & 20.70 \\
\hline 23/01/2008 09:00 & 5.94 & 1.03 & 83.72 & 6.19 & 5.44 & 24.50 \\
\hline 24/01/2008 09:00 & 7.97 & 1.02 & 94.18 & 6.47 & 5.72 & 23.09 \\
\hline $25 / 01 / 200809: 00$ & \multicolumn{6}{|c|}{ Invalid data } \\
\hline 26/01/2008 09:00 & 4.36 & 0.02 & 106.17 & 7.31 & 6.46 & 27.56 \\
\hline $27 / 01 / 200809: 00$ & 8.00 & 0.87 & 106.97 & 6.61 & 5.94 & 23.81 \\
\hline 28/01/2008 09:00 & 5.88 & 0.92 & 107.59 & 6.65 & 5.87 & 25.49 \\
\hline 29/01/2008 09:00 & 5.15 & 1.30 & 79.60 & 7.06 & 6.24 & 26.28 \\
\hline 30/01/2008 09:00 & 6.73 & 3.72 & 36.66 & 6.55 & 5.94 & 25.68 \\
\hline 31/01/2008 09:00 & 3.33 & 1.49 & 26.68 & 7.38 & 6.51 & 28.85 \\
\hline 01/02/2008 09:00 & 7.07 & 1.25 & 68.61 & 6.26 & 5.62 & 23.11 \\
\hline 02/02/2008 09:00 & 3.19 & 1.73 & 92.41 & 7.43 & 6.67 & 29.57 \\
\hline \begin{tabular}{|l|}
$03 / 02 / 200809: 00$ \\
\end{tabular} & 6.97 & 1.41 & 97.97 & 6.70 & 6.00 & 23.78 \\
\hline 04/02/2008 09:00 & 5.16 & 8.34 & 91.00 & 6.94 & 6.08 & 27.26 \\
\hline 05/02/2008 09:00 & 6.65 & 0.13 & 128.27 & 6.72 & 5.97 & 24.77 \\
\hline 06/02/2008 09:00 & 10.93 & 3.95 & 102.14 & 4.87 & 4.33 & 17.02 \\
\hline 07/02/2008 09:00 & 8.12 & 0.12 & 133.18 & 5.56 & 4.89 & 21.42 \\
\hline 08/02/2008 09:00 & 7.44 & 4.14 & 138.24 & 6.25 & 5.58 & 23.19 \\
\hline 09/02/2008 09:00 & 6.93 & 1.97 & 138.62 & 6.30 & 5.60 & 23.58 \\
\hline \begin{tabular}{|l|}
$10 / 02 / 200809: 00$ \\
\end{tabular} & 6.22 & 1.60 & 137.64 & 6.55 & 5.79 & 24.54 \\
\hline 11/02/2008 09:00 & 8.94 & 2.44 & 134.56 & 6.25 & 5.62 & 23.38 \\
\hline 12/02/2008 09:00 & 6.91 & 1.71 & 144.15 & 6.22 & 5.46 & 23.58 \\
\hline 13/02/2008 09:00 & 8.50 & 1.95 & 143.57 & 6.17 & 5.48 & 22.61 \\
\hline 14/02/2008 09:00 & 6.87 & 1.31 & 115.38 & 5.90 & 5.10 & 22.09 \\
\hline 15/02/2008 09:00 & 6.12 & 0.37 & 152.56 & 6.43 & 5.83 & 24.62 \\
\hline 16/02/2008 09:00 & 7.71 & 1.05 & 161.24 & 6.34 & 5.71 & 22.82 \\
\hline 17/02/2008 09:00 & 8.87 & 1.97 & 176.31 & 5.42 & 4.73 & 20.59 \\
\hline 18/02/2008 09:00 & 10.49 & 1.20 & 148.89 & 5.19 & 4.59 & 17.92 \\
\hline 19/02/2008 09:00 & 12.02 & 1.74 & 103.04 & 3.91 & 3.47 & 14.21 \\
\hline $20 / 02 / 200809: 00$ & 9.76 & 0.77 & 42.82 & 4.41 & 3.81 & 16.49 \\
\hline 21/02/2008 09:00 & 11.38 & 0.77 & 154.30 & 4.09 & 3.70 & 16.67 \\
\hline
\end{tabular}


Table 5: Daily weather conditions and energy consumptions on the north of Europe site.

\begin{tabular}{|c|c|c|c|c|c|c|}
\hline \multicolumn{7}{|c|}{ North of Europe } \\
\hline Date & $\operatorname{Temp}\left({ }^{\circ} \mathrm{C}\right)$ & $\begin{array}{c}\text { Wind } \\
\text { speed } \\
(\mathrm{m} / \mathrm{s})\end{array}$ & $\begin{array}{c}\text { Solar } \\
\text { radiation } \\
\left(\mathrm{W} / \mathrm{m}^{2}\right)\end{array}$ & $\begin{array}{c}\text { kWh } \\
\text { MF }\end{array}$ & $\begin{array}{l}\text { kWh } \\
\text { MW }\end{array}$ & $\begin{array}{c}\text { kWh } \\
\text { Not insulated }\end{array}$ \\
\hline 01/02/2008 09:00 & 1.61 & 4.44 & 14.11 & 7.74 & 4.96 & 32.07 \\
\hline $02 / 02 / 200809: 00$ & 1.88 & 4.17 & 31.64 & 7.73 & 5.08 & 31.17 \\
\hline 03/02/2008 09:00 & 0.44 & 3.11 & 66.52 & 8.17 & 5.27 & 31.94 \\
\hline $04 / 02 / 200809: 00$ & 1.73 & 3.44 & 66.69 & 7.75 & 4.98 & 28.85 \\
\hline 05/02/2008 09:00 & 2.14 & 2.31 & 7.53 & 7.07 & 4.58 & 26.66 \\
\hline 06/02/2008 09:00 & 4.00 & 2.64 & 25.43 & 6.54 & 4.22 & 24.23 \\
\hline $07 / 02 / 200809: 00$ & 3.76 & 1.49 & 33.06 & 6.57 & 4.27 & 24.73 \\
\hline 08/02/2008 09:00 & 2.30 & 1.06 & 26.18 & 6.78 & 4.43 & 25.62 \\
\hline 09/02/2008 09:00 & 3.88 & 2.94 & 52.27 & 6.65 & 4.26 & 25.92 \\
\hline 10/02/2008 09:00 & 3.44 & 3.89 & 31.72 & 6.76 & 4.34 & 27.63 \\
\hline 11/02/2008 09:00 & 0.59 & 1.87 & 7.21 & 7.63 & 4.88 & 29.92 \\
\hline $12 / 02 / 200809: 00$ & \multirow{4}{*}{\multicolumn{6}{|c|}{ Invalid data }} \\
\hline 13/02/2008 09:00 & & & & & & \\
\hline $14 / 02 / 200809: 00$ & & & & & & \\
\hline 15/02/2008 09:00 & & & & & & \\
\hline 16/02/2008 09:00 & -6.17 & 2.50 & 94.55 & 10.89 & 7.25 & 39.31 \\
\hline 17/02/2008 09:00 & 0.36 & 4.48 & 11.99 & 8.63 & 6.01 & 32.48 \\
\hline $18 / 02 / 200809: 00$ & 2.27 & 3.35 & 18.91 & 7.38 & 5.02 & 27.14 \\
\hline 19/02/2008 09:00 & -0.57 & 2.58 & 93.72 & 8.46 & 5.56 & 38.69 \\
\hline $20 / 02 / 200809: 00$ & 2.27 & 2.47 & 31.95 & 7.38 & 5.00 & 27.66 \\
\hline $21 / 02 / 200809: 00$ & 3.85 & 3.41 & 45.41 & 6.65 & 4.37 & 25.86 \\
\hline $22 / 02 / 200809: 00$ & 6.78 & 7.12 & 17.18 & 5.93 & 4.37 & 23.51 \\
\hline $23 / 02 / 200809: 00$ & 4.36 & 5.65 & 22.23 & 6.96 & 5.14 & 26.89 \\
\hline 24/02/2008 09:00 & 6.79 & 4.74 & 10.47 & 5.92 & 4.12 & 22.46 \\
\hline $25 / 02 / 200809: 00$ & 4.28 & 4.99 & 25.55 & 6.58 & 4.62 & 25.97 \\
\hline $26 / 02 / 200809: 00$ & 6.75 & 4.28 & 58.22 & 5.71 & 3.88 & 22.19 \\
\hline 27/02/2008 09:00 & 5.39 & 5.94 & 36.40 & 6.11 & 4.28 & 25.13 \\
\hline $28 / 02 / 200809: 00$ & 3.69 & 5.27 & 60.18 & 7.11 & 5.10 & 27.73 \\
\hline $29 / 02 / 200809: 00$ & 3.32 & 3.31 & 33.39 & 6.86 & 4.71 & 26.15 \\
\hline 01/03/2008 09:00 & 3.56 & 3.77 & 12.93 & 6.58 & 4.41 & 25.32 \\
\hline 02/03/2008 09:00 & 2.44 & 5.40 & 24.37 & 7.43 & 5.29 & 29.08 \\
\hline 03/03/2008 09:00 & 1.85 & 3.08 & 44.00 & 7.52 & 5.21 & 28.64 \\
\hline 04/03/2008 09:00 & -0.20 & 3.39 & 118.53 & 8.28 & 5.68 & 31.31 \\
\hline 05/03/2008 09:00 & 0.19 & 3.20 & 109.21 & 8.21 & 5.58 & 31.35 \\
\hline 06/03/2008 09:00 & 1.17 & 4.98 & 30.78 & 7.94 & 5.41 & 32.85 \\
\hline 07/03/2008 09:00 & 2.27 & 2.59 & 101.26 & 7.30 & 4.94 & 27.24 \\
\hline 08/03/2008 09:00 & 4.45 & 1.23 & 55.65 & 6.16 & 4.08 & 21.98 \\
\hline 09/03/2008 09:00 & 5.95 & 1.56 & 52.99 & 5.61 & 3.70 & 20.29 \\
\hline
\end{tabular}

Table 6: Energy consumptions on the three test sites during the entire test period.

\begin{tabular}{|l|c|c|c|c|}
\cline { 3 - 5 } \multicolumn{2}{c|}{} & \multicolumn{3}{c|}{ Energy consumption (kWh) } \\
\hline \multicolumn{1}{c|}{ Site } & Days of test & MF & MW & Not insulated \\
\hline South of Europe & 34 & 229.5 & 219.0 & 810.3 \\
\hline Centre of Europe & 27 & 223.5 & 197.4 & 841.4 \\
\hline North of Europe & 34 & 245.0 & 165.0 & 948.0 \\
\hline
\end{tabular}


Table 7: $\quad$ Thermal transmittance of the tested cells.

\begin{tabular}{|l|c|c|c|c|c|}
\hline & \multicolumn{3}{|c|}{ Thermal transmittance $\left(\mathrm{W} / \mathrm{m}^{2} \mathrm{~K}\right)$} & \multicolumn{2}{c|}{ Energy savings } \\
\hline \multicolumn{1}{|c|}{ Site } & MF & MW & Not insulated & MF & MW \\
\hline South of Europe & 0.37 & 0.35 & 1.32 & $72 \%$ & $73 \%$ \\
\hline Centre of Europe & 0.37 & 0.32 & 1.39 & $73 \%$ & $77 \%$ \\
\hline North of Europe & 0.39 & 0.26 & 1.50 & $74 \%$ & $83 \%$ \\
\hline
\end{tabular}

Table 8:

Comparison between in situ measurements and the Trnsys ${ }^{\circledR}$ simulation.

\begin{tabular}{|c|c|c|c|c|c|c|c|c|}
\hline \multicolumn{9}{|c|}{ South of Europe } \\
\hline & \multicolumn{4}{|c|}{ MW } & \multicolumn{4}{|c|}{ MF } \\
\hline \multirow{3}{*}{\begin{tabular}{|l|} 
Configuration \\
Without thermal bridges \\
Thermal bridges (Sext) \\
\end{tabular}} & $\begin{array}{l}\text { In situ } \\
(\mathrm{kWh})\end{array}$ & $\begin{array}{l}\text { Trmsys } \\
\text { (kWh) }\end{array}$ & $\begin{array}{c}\text { Ecart } \\
\text { (Trnsys-ln situ) }\end{array}$ & $\begin{array}{l}\text { Air change to fit } \\
\text { measurements (h-1) }\end{array}$ & $\begin{array}{l}\text { In situ } \\
(\mathrm{kWh})\end{array}$ & $\begin{array}{l}\text { Trnsys } \\
(\mathrm{kWh})\end{array}$ & $\begin{array}{c}\text { Ecart } \\
\text { (Trnsys-In situ) }\end{array}$ & $\begin{array}{l}\text { Air change to fit } \\
\text { measurements (h-1) }\end{array}$ \\
\hline & \multirow{2}{*}{218.96} & 121.11 & $-45 \%$ & 0.73 & \multirow{2}{*}{229.546} & 243.83 & $6 \%$ & - \\
\hline & & 156.51 & $-29 \%$ & 0.46 & & 328.99 & $43 \%$ & - \\
\hline \multicolumn{9}{|c|}{ Centre of Europe } \\
\hline & \multicolumn{4}{|c|}{ MW } & \multicolumn{4}{|c|}{ MF } \\
\hline \multirow{3}{*}{\begin{tabular}{|l} 
Configuration \\
Without thermal bridges \\
Thermal bridges (Sext)
\end{tabular}} & $\begin{array}{l}\text { In situ } \\
(\mathrm{kWh})\end{array}$ & $\begin{array}{l}\text { Trnsys } \\
\text { (kWh) }\end{array}$ & $\begin{array}{c}\text { Ecart } \\
\text { (Trnsys-In situ) }\end{array}$ & $\begin{array}{l}\text { Air change to fit } \\
\text { measurements ( } h-1)\end{array}$ & $\begin{array}{l}\text { In situ } \\
(\mathrm{kWh})\end{array}$ & $\begin{array}{l}\text { Trnsys } \\
(\mathrm{kWh})\end{array}$ & $\begin{array}{c}\text { Ecart } \\
\text { (Trnsys-In situ) }\end{array}$ & $\begin{array}{l}\text { Air change to fit } \\
\text { measurements }(\mathrm{h}-1)\end{array}$ \\
\hline & \multirow{2}{*}{197.39} & 128.09 & $-35 \%$ & 0.50 & \multirow{2}{*}{223.46} & 257.08 & $15 \%$ & - \\
\hline & & 163.21 & $-17 \%$ & 0.24 & & 344.27 & $54 \%$ & 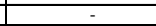 \\
\hline
\end{tabular}

\begin{tabular}{|c|c|c|c|c|c|c|c|c|}
\hline \multicolumn{9}{|c|}{ North of Europe } \\
\hline & \multicolumn{4}{|c|}{ MW } & \multicolumn{4}{|c|}{ MF } \\
\hline Configuration & $\begin{array}{l}\text { In situ } \\
(\mathrm{kWh})\end{array}$ & $\begin{array}{l}\text { Tmsys } \\
\text { (kWh) }\end{array}$ & $\begin{array}{c}\text { Ecart } \\
\text { (Trnsys-In situ) }\end{array}$ & $\begin{array}{l}\text { Air change to fit } \\
\text { measurements (h-1) }\end{array}$ & $\begin{array}{l}\text { In situ } \\
(\mathrm{kWh})\end{array}$ & $\begin{array}{l}\text { Trnsys } \\
\text { (kWh) }\end{array}$ & $\begin{array}{c}\text { Ecart } \\
\text { (Trnsys-In situ) }\end{array}$ & $\begin{array}{l}\text { Air change to fit } \\
\text { measurements (h-1) }\end{array}$ \\
\hline Without thermal bridges & 164.99 & 126.95 & $-23 \%$ & 0.28 & 24503 & 241.54 & $-1 \%$ & 0.03 \\
\hline Thermal bridges (Sext) & 164.99 & 166.43 & $1 \%$ & - & 245.03 & 327.81 & $34 \%$ & - \\
\hline
\end{tabular}

Table 7 shows that the thermal performance of MF is higher in the south and centre of Europe compared to the north of Europe. MW has an opposite effect with higher performance on the north of Europe and lower in the south. The same table presents the energy savings of each insulated cell compared to the non-insulated cell. One can see that in the north of Europe, the MW has higher energy savings than the MF. This is different on the two other sites where the cell insulated with MF and the one insulated with MW have very similar energy savings.

\subsection{Simulation results}

The results presented in this section have been obtained with TRNSYS ${ }^{\circledR}$ software [7]. The simulations have been performed using the exact geometry of the cells and the weather conditions registered on each test centre. The input thermal properties of each wall of the structure are determined using standardised methods for measurement and calculation $[1,2,5]$. The simulation results in terms of energy consumption are compared with measurements in table 8 .

If the linear thermal bridges are not taken into account then the simulation results for the MW cell fit with the measurements using a level of air infiltration between $0.28 \mathrm{~h}^{-1}$ and $0.73 \mathrm{~h}^{-1}$. If thermal bridges are taken into account by considering the external surface of the cell as heat loss surface than the level of air infiltration to fit simulation results with measurements is considerably reduced (max value is $0.46 \mathrm{~h}^{-1}$ ). 
For MF cell, simulations overestimated the energy needed to maintain the temperature set point into the cells even without taking into account the linear thermal bridges effect. Moreover, as shown in table 2, the cells air tightness is very similar and therefore the same level of infiltration found for MW cells should be applied to the MF one. In this case the difference between simulations and measurements is up to $70 \%$. This inconsistency could be explained by the underestimation of the thermal performance of MF + adjacent air gaps. This raises the question of the efficiency of traditional methods and the need for a new suitable method to determine the correct resistive characteristics of the cavities with reflective walls. A three dimensional CFD model coupling the different heat transfer mechanisms could allow a better understanding of the thermal behaviour of MF product.

\section{Conclusion}

The in situ tests performed in regions of Europe with different weather conditions have showed that the thermal performance of the MF product is clearly underestimated by the standard measurements and calculations currently employed. The weather conditions seem to have a high impact on the thermal performance of different insulation systems. The difference between calculation and in situ measurement is lower on the site situated in north of Europe probably because the test conditions are very similar with those imposed by the standard methods i.e. very low temperature variation. The highest difference between calculation and measurement is obtained in the south of Europe where the weather conditions are completely different from those imposed by standards: high temperature variation during the course of one day. This clearly shows that the actual standards are not appropriate to determine the true thermal performance of MF products.

The protocol detailed in this paper also allows the direct determination of the energy saving using a given insulation system in comparison with a noninsulated cell. It appears that the MF solution allows a significant energy saving and, therefore, this solution can be an interesting alternative especially for old buildings where the space for thick insulation is not available.

\section{Acknowledgement}

We would like to thank all people helping us in this project: T. Labrousse, F. Laché, B. Saintpeyre, B. Sanchez, T. Bonnafoux.

\section{References}

[1] ISO 8302, Thermal Insulation. Determination of steady-state thermal resistance and related properties -- Guarded hot plate apparatus.

[2] ISO 8990, Thermal insulation. Determination of steady-state thermal transmission properties - Calibrated and guarded hot box. 
156 Computational Methods and Experimental Measurements XIV

[3] Report BRE $n^{\circ} 78132$, Fields investigations of the thermal performance of construction elements as built, June 2001.

[4] ISO 6946, Building components and building elements - Thermal resistance and thermal transmittance - Calculation method.

[5] ACTIS guideline on http://www.actis-isolation.com

[6] Example of set up on: http://www.knaufinsulation.co.uk/PDF/Book_3_2_2_ Pitched_Roofs_Rafter_Level.pdf

[7] http://sortware.cstb.fr/soft/present.asp?page_id=fr!Trnsys 